\title{
Negative Solvatochromism of Ferrocenyl Methine Dyes
}

\author{
Abdullah M. Asiri and ${ }^{1}$ Muhammed S. Al-Amoudi \\ Chemistry Department, Faculty of Science, King Abdulaziz University, \\ Jeddah, and ${ }^{1}$ Taif University, Saudi Arabia \\ aasiri2@kau.edu.sa
}

\begin{abstract}
A novel solvatochromic ferrocenyl methine dyes has been synthesized by condensation of ferrocen-3-caboxaldehyde with active methylene compounds under Knoevengel conditions and characterized by UV-vis in a range of solvents. Compound 1a has a red shift in $\pi-\pi^{*}$ and a blue shift increases with solvent polarity in the MLCT $(\mathrm{M} \rightarrow \mathrm{A})$ while $1 \mathrm{~b}-1 \mathrm{~d}$ variation of red as well as blue shifts from both states. No $\mathrm{d}-\mathrm{d}$ transition is observed in these compounds. These shifts are interpreted by different dipole moments in the ground and excited state as well as solvent interaction between solute/solvent and $\mathrm{H}$ bonding with the acceptor.
\end{abstract}

\section{Introduction}

We reported the preparation and characterization of new ferrocenylbased methines with an end capped with different electron-withdrawing groups ${ }^{[1-3]}$. Here, we report the synthesis of ferrocenyl methine dyes by the condensation of ferroce-3-carboxaldehyde with active methylene compounds under Konovengel conditions to afford a new methine dyes with absorption maximum in the visible region (Scheme 1).

The interest in the use of blue shift organic and organometallic molecules for Second Order Non-Linear Optical (SONLO) devices prompted us to study the electronic structure of these ferrocenyl methines. Solvatochromic effects may give an indication of the magnitude expected for nonlinear optical properties since it reflects the polarizability of a chromophore ${ }^{[4-6]}$. The absorption maximum measured in solvents of increasing polarity is given in Table 1. Figure 1 shows MLCT for the four compounds in different solvents (Toluene, 
THF, $\mathrm{CHCl}_{3}$.acetone and ethanol) while Fig. 2 represents the effect of these solvents for $1 \mathrm{a}$.

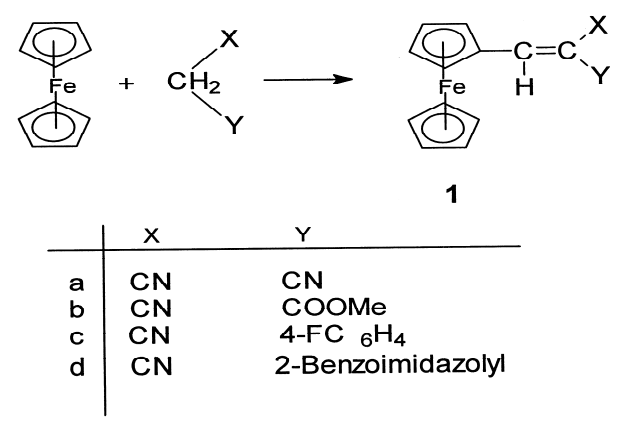

Scheme 1

Table 1. Absorption spectral data of methine dyes 1a-1d in various solvents.

\begin{tabular}{|c|c|c|c|c|c|c|c|c|c|c|c|c|}
\hline \multicolumn{11}{|c|}{$\lambda \max$} & \multirow{2}{*}{\multicolumn{2}{|c|}{. }} \\
\hline $\begin{array}{c}\text { Dye } \\
\#\end{array}$ & \multicolumn{2}{|c|}{$\begin{array}{l}\text { Toulene } \\
\text { (33.9)* }\end{array}$} & \multicolumn{2}{|c|}{$\begin{array}{c}\text { THF } \\
(37.4) \\
\end{array}$} & \multicolumn{2}{|c|}{$\begin{array}{c}\mathrm{CH}_{3} \mathrm{Cl} \\
(39.1) \\
\end{array}$} & \multicolumn{2}{|c|}{$\begin{array}{c}\text { Acetone } \\
(42.2)\end{array}$} & \multicolumn{2}{|c|}{$\begin{array}{l}\text { EtOH } \\
(51.9)\end{array}$} & & \\
\hline & $\pi \rightarrow \pi^{*}$ & MLCT & $\Pi^{*} \rightarrow \pi$ & MLCT & $\pi^{*} \rightarrow \pi$ & MLCT & $\pi \rightarrow \pi^{*}$ & MLCT & $\pi \rightarrow \pi^{*}$ & MLCT & $\pi \rightarrow \pi^{*}$ & MLCT \\
\hline 1a & 325 & & 394 & & 392 & 531 & 395 & 521 & 392 & 475 & 4945 & 4913 \\
\hline $1 b$ & 329 & 515 & 320 & 514 & 322 & 521 & 331 & 517 & 334 & 517 & 10881 & 2023 \\
\hline $1 \mathrm{c}$ & 343 & 487 & 336 & 488 & 328 & 495 & 334 & 485 & 326 & 486 & 35000 & 3715 \\
\hline $1 d$ & 363 & 509 & 358 & 503 & 362 & 518 & 349 & 503 & 357 & 512 & 17000 & 2613 \\
\hline
\end{tabular}

*The solvent parameters $\mathrm{E}_{\mathrm{T}}$ in $\mathrm{kcal}$. $\mathrm{Mol}^{-1}$.

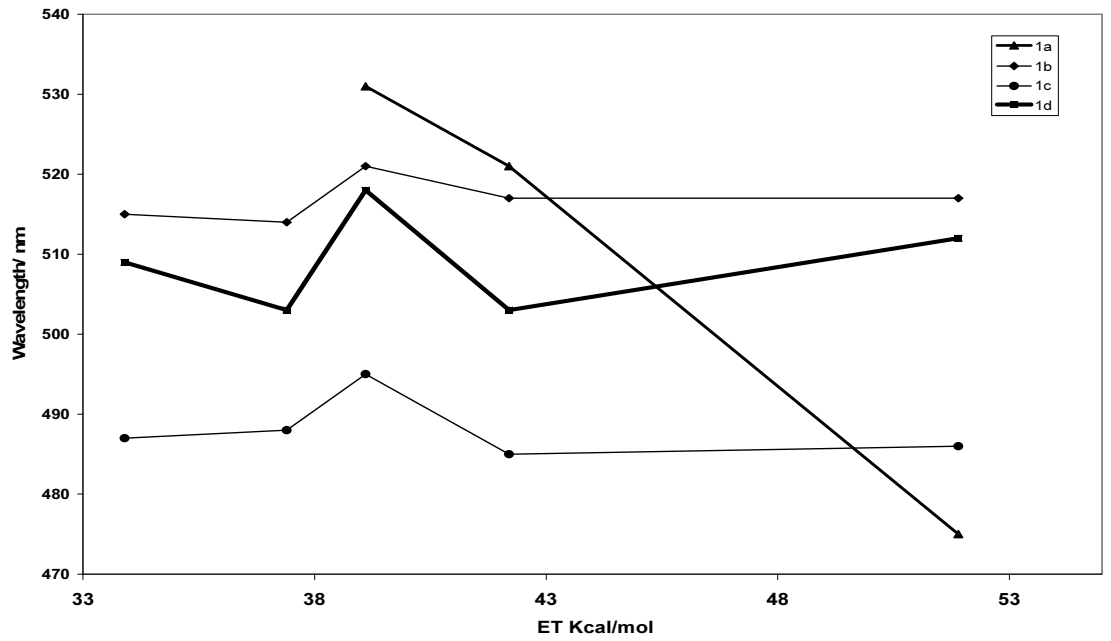

Fig. 1. MLCT transition in different solvents. 


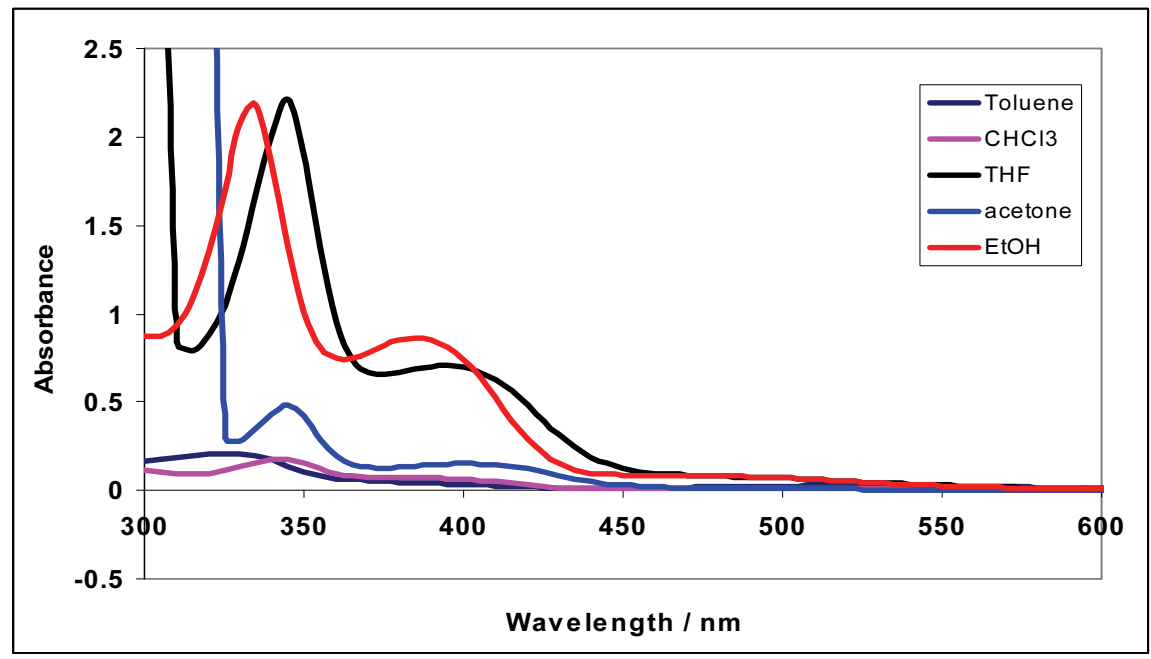

Fig. 2. UV-Vis absorption of 1a in different solvents.

In general, the electronic absorption of these dyes show one band between 325 and $395 \mathrm{~nm}$ assigned to $\pi-\pi^{*}$ transition and another one at a longer wavelength between $509-521 \mathrm{~nm}$ due to metal-to-ligand charge transfer (MLCT) and no absorption observed for d-d transition unless it is covered by the broad LMCT band. These assignments are based on theoretical results reported by Barlow et al. ${ }^{[3]}$ and other experimental findings ${ }^{[7-10]}$. The two bands are strongly influenced by the nature of the acceptor group as well as by the polarity of the solvent. The band from $\pi$ $\pi^{*}$ transition for 1a showed a red shit on increasing the solvent polarity $(\delta$ $70 \mathrm{~nm}$ ), but the shift is not linear with the solvent polarity indicating that the mesomoric form (Scheme 2) lowers the energy of the $\pi^{*}$ orbital and the difference in dipole moment between ground and excited is small. However, the lower energy band from MLCT, unlike $\pi-\pi^{*}$, showed a clear dependence on the nature of solvent polarity with maximum $\delta 56$ $\mathrm{nm}$ blue shifted. These different shifts are not attributed to the solvent polarity alone, but to the interaction of the solute/solvent and the nature of hydrogen bonding ability between solvent/dye as well. From the large shifts observed for 1a, we conclude that it has larger polarazability compared with $1 \mathrm{~b}-1 \mathrm{~d}$ due cyano electron withdrawing groups. The negative bathochromic shift is certainly due to opposite in sign between the dipole moments of the ground and excited states ${ }^{[3]}$. Compounds $1 \mathrm{~b}-1 \mathrm{~d}$ showed red as well as blue shift from both transition ( $\pi-\pi^{*}$ and MLCT). 
It can be attributed to weak acceptor groups replacing the cyano moiety and also the small dipole moment difference between ground and excited states and with opposite signs.

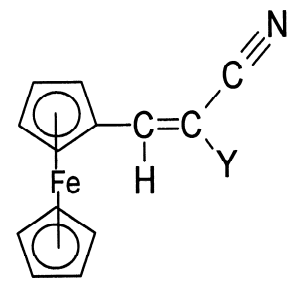

1

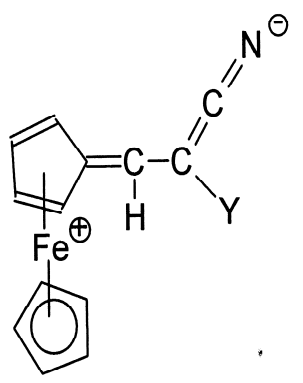

Scheme 2

\section{Experimental}

\section{General Procedure}

Typical procedure for the synthesis of dyes 1a-1d: To a refluxed solution of ferrocenecaboxaldehyde $(10 \mathrm{ml})$ and the active methylene $(10$ $\mathrm{ml})$ in ethanol $(50 \mathrm{ml})$, piperdine $(1 \mathrm{ml})$ was added. After the addition, the solution became darker and the reflux wad continued for six hours, then the solution was left to cool to room temperature and the products were precipitated. The precipitate were filtered and washed with cold water and finally with ethanol, dried and recrystalized from the appropriate solvent.

\section{1,1-Dicyanovinyl-2-Ferrocene (1a)}

Deep red crystals, yield 50\%; m.p. 231-233 C Anal. Found; C. 64.02; H, 3.95; N, 10.47. $\mathrm{C}_{14} \mathrm{H}_{10} \mathrm{~N}_{2}$ Fe Cal. C, 64.18; H, 3.82; N, 10.68\% $v_{\max }\left(\mathrm{KBr} / \mathrm{cm}^{-1}\right) 2185,2170(\mathrm{CN}), 1630(\mathrm{C}=\mathrm{C}), 1101,992,814 .{ }^{1} \mathrm{H}-\mathrm{NMR}$ $\delta 7.70(\mathrm{~s}, 1 \mathrm{H},-\mathrm{CH}==\mathrm{C}), 5.01$ (broad s, 2H, H-2, H-4, H-5), 4.85 (broad s, 2H, H-2, H3, H-4), 4.33 (s, 5H, C5H5).

\section{(Z)- 1-Cyano-1-Methoxcarbonylvinylferrocene (1b)}

Red crystals, yield $98 \%$; m.p. $80-82^{\circ}$ C. Anal. Found; C, 60.88; H, 4.65; N, 4.51. $\mathrm{C}_{15} \mathrm{H}_{13} \mathrm{O}_{2} \mathrm{NFe}$ Calc.: C, 61.07; H, 4.41; N, $4.75 \%$. vmax 
$\left(\mathrm{KBr} / \mathrm{cm}^{-1}\right) 2222(\mathrm{CN}), 1730(\mathrm{C}=\mathrm{O}), 1600(\mathrm{C}=\mathrm{C}), 1105,990,815 .{ }^{1} \mathrm{H}-$ NMR: $\delta 8.20(\mathrm{~s}, 1 \mathrm{H},-\mathrm{CH}=\mathrm{C}), 5.04($ broad s, 2H, H-2, H4, H-5), 4.74 (broad s, 2H, H-2, H3, H-4), 4.33 (d, 3H, $J=3.5 \mathrm{~Hz}, \mathrm{CH} 3 \mathrm{O}), 4.27$ (s, $5 \mathrm{H}$, $\left.\mathrm{C}_{5} \mathrm{H}_{5}\right)$.

\section{1-Cyan-1- [4-Toluyl] Vinylferrocene (1c)}

Red crystals, yield $88 \%$; m.p. $120-122^{\circ} \mathrm{C}$. Anal. Found; C, 61.05; H, 5.36; N, 4.12. $\mathrm{C}_{20} \mathrm{H}_{17} \mathrm{NFe}$ Calc.: C, 61.19; H, 5.20; N, $4.28 \%$. vmax $\left(\mathrm{KBr} / \mathrm{cm}^{-1}\right) 2022(\mathrm{CN}), 1615(\mathrm{C}=\mathrm{C}), 1100,997,811 .{ }^{1} \mathrm{H}-\mathrm{NMR}: \delta 7.49(\mathrm{~d}$, $2 \mathrm{H}, J=8.1 \mathrm{~Hz}), 7.34(\mathrm{~s}, 1 \mathrm{H},-\mathrm{CH}=\mathrm{C}), 7.21(\mathrm{~d}, 2 \mathrm{H}, J=8.1 \mathrm{~Hz}), 4.96$ (broad s, 2H, H-2, H4, H-5), 4.52 (broad s, 2H, H-2, H3, H-4), 4.23 (s, $\left.5 \mathrm{H}, \mathrm{C}_{5} \mathrm{H}_{5}\right), 2.37\left(\mathrm{~s}, 3 \mathrm{H}, \mathrm{CH}_{3}\right)$.

\section{1-Cyano-1- [2-Benzoimidazoly] Vinylferrocene (1d)}

Dark red crystals, yield 55\%; m.p. $>300^{\circ} \mathrm{C}$. Anal. Found; C, 67.87; $\mathrm{H}, 4.52 ; \mathrm{N}, 11.75 . \mathrm{C}_{20} \mathrm{H}_{15} \mathrm{~N}_{3} \mathrm{Fe}$ Calc.: C, 68.04; H, 4.25; N, 11.90\%. vmax $\left(\mathrm{KBr} / \mathrm{cm}^{-1}\right) 3100(\mathrm{NH}), 2220(\mathrm{CN}), 1585(\mathrm{C}=\mathrm{C}), 1100,990,815 .{ }^{1} \mathrm{H}-$ NMR: $\delta 9.69$ broad s, 1H, exchange with D2O, NH), $8.39(\mathrm{~s}, 1 \mathrm{H}$, $\mathrm{CH}=\mathrm{C}$ ), 7.87 (broad s, 1H, H-4 benzoimidazolyl), 7.57 (broad s, 1H, H-6 benzoimidazolyl), 7.29 (broad s, 2H, H-5, H-7 benzoimidazolyl)), 5.01 (broad s, 2H, H-2, H4, H-5), 4.68 (broad s, 2H, H-2, H3, H-4), 4.27 (s, $\left.5 \mathrm{H}, \mathrm{C}_{5} \mathrm{H}_{5}\right)$.

\section{References}

[1] Asiri, A.M., Appl. Organometl Chem., 15:907 (2001).

[2] Asiri, A.M., Iqbal, M.I., Al-Amry, K.A. and Fatani, N.A., Dyes and Pigments, 67: 111 (2005).

[3] Barlow, S., et al., J. Am. Chem. Soc., 122: 3715 (1999).

[4] Wang, H., et al., Eu. J. Inorg. Chem., 200: 683 (2000).

[5] Paley, M.S., et al., J. Org. Chem., 54: 3774, (1989).

[6] McRae, E.G., et al., J. Phys.Chem., 61: 562 (1957).

[7] Mata, J.A., et al., J. Organomet. Chem., 563: 197 (1998).

[8] Colobresse, J.C., et al., J. Am. Chem. Sov., 113: 7227 (1991).

[9] Houlton, A., et al., Inorg. Chem. Acta., 205: 67 (1993).

[10] Schumm, J.S., et al., Angew. Chem. Int. Ed. Engl., 33: 1360 (1994). 
تأثير مذيب سلبي لأصباغ الميثان المشتقة من الفروسين

عبدالله محمد عسيري ، و محمد سعيد العمودي

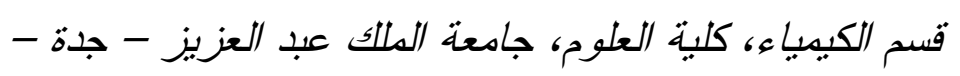

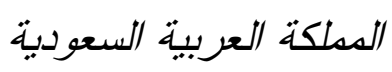

المستخلص. لوحظ أثز مذيب سلبي لأصباغ الميثان المشتقة من الفروسين،

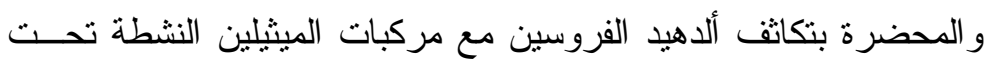

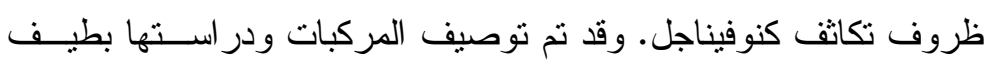

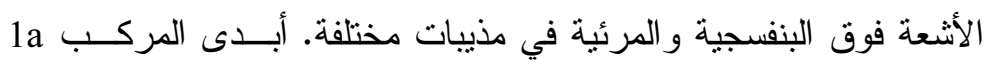
إز احة حمر اء في قمة الامتصاص في المجال غير المرئي و إز احة زرقاء للقمة المتمركزة في المجال المرئي، وتزداد الإز احة بزيادة قطبية المذيب.

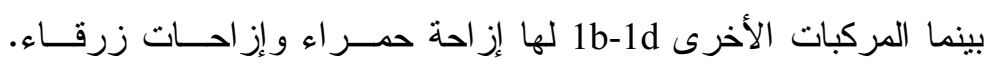
ويعزى السبب في الأثر السلبي للمذيب على هذه المركبات، إلى الاختلاف

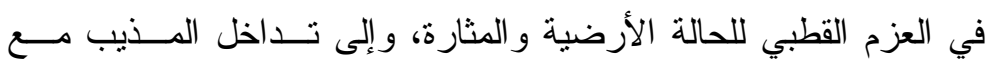
المذاب، وكذللك الرو ابط الهيدروجينية للمستقبل. 